\title{
舌血管腫にみられた静脈石の分析
}

\author{
五島博樹・角田左武郎・堀滋・木村義孝 \\ 南雲正男・江川 薰*・滝口励司*
}

\section{Analysis of phlebolite in a tongue hemangioma}

\author{
Hiroki Gотон • Saburoh KakUta - Sigeru Hori • Yositaka KrmuRA \\ Masao Nagumo $\cdot$ Kaoru Egawa - Reiji Takiguti
}

\begin{abstract}
We have experienced a case of analyzing hemangioma with multiple phlebolite on the right tip of the tongue. The phlebolite were observed with Scanning electron microscopy (SEM) and Contact microradiography (CMR). The stone components were also analyzed by chemical method and X-ray microanalyzer.

The observation of SEM and CMR showed that stratiform calcification took place and their internal structures were slightly different depending upon the sizes of stones. The constitution of stones was $8 \%$ water, $7 \%$ organic matter and $85 \%$ mineral. Preponderance of minerals were calcium and phosphorus. $\mathrm{Ca} / \mathrm{P}$ ratios calculated by the chemical analysis and $\mathrm{X}$-ray elemental analysis were similar to that of hydroxyapatite.
\end{abstract}

Key words: tongue hemangioma, phlebolite, calcification

緒

言

血管腫は血管組織が増生した良性の腫汪で，口腔領域 に扒いては煩部，口唇，舌などに好発する，血管腫はと きにその組織内に静脈石を伴うか，多数の静脈石を伴っ た症例の報告は比較的少ない. 今回われわれは，右側舌 尖部に発生し，多数の静脈石を有した血管腫の一例を経 験した。 そこで，その概要とともに，摘出した静脈石に ついてX線元素分析, 成分分析, および走査型電子顕微 鏡によるその内部構造の観察を行ったので，それらの結 果をあわせて報告する.

昭和大学第 2 口腔外科学教空

（主任：南雲正男教授）

* 昭和大学第 1 口腔解剖学教室

（主任：滰口励司教授）

The Second Department of Oral Surgery, School of Dentistry, Showa University (Chief: Prof. Masao Nagumo)

* The First Department of Oral Anatomy, School of Dentistry, Showa University (Chief: Prof. Reiji Takiguti)

受付日：昭和 62 年 11 月 25 日
症

例

患 者: 35歳 女性

初 診: 昭和 60 年 8 月曰日.

主 訴: 右側舌尖部の尰瘤.

既往歴・家族歴：特記事項なし。

現病歴：約 25 年前, 自転車で転倒し舌を咬んた。 転倒 時, 創部より軽度の出血はみられたが, 腫脹, 疼痛忖す ぐに消失した。そその後，右側舌尖部が徐々に腫镺してき たが，疼痛がなかったためにそのまま放置していた。最 近, 腫脹部に白色の硬固物が存在するのに気付き, 精査 のため某歯科医を受診したところ，当科を紹介され昭和 60 年 8 月曰日来院した。

口腔内所見：右側舌尖部に比較的境界明瞭な母指頭大 ほどの腫瘤が認められた。腫瘤は弾性軟で, 表面は暗赤 紫色を呈していた（写真１）。また，腫瘤内には白色の 硬固物が認められた（写真 2)。なお，自発痛，压痛は なかった。

$\mathbf{X}$ 線所見 : 右側舌尖部の腫瘤内に多数の大小不同の $\mathrm{X}$ 線不透過像が認められた（写真了）。

臨床検查所見：一般血液検查拈よび生化学的検査で は，特に異常所見はみられなかった。

臨床診断：結石を伴った舌血管腫. 


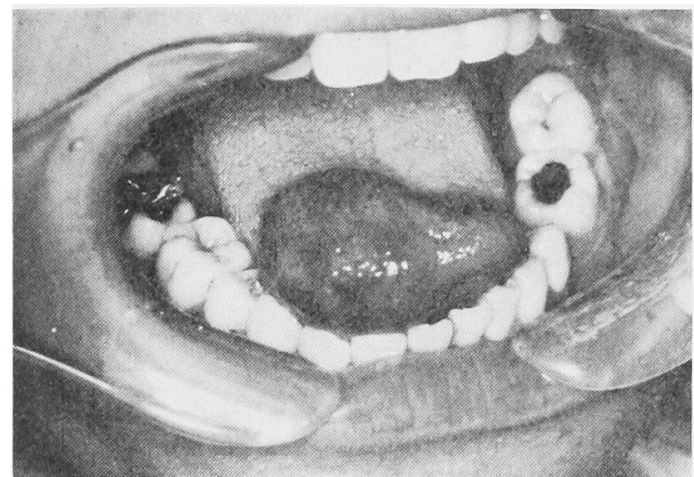

写真 1 口腔内所見

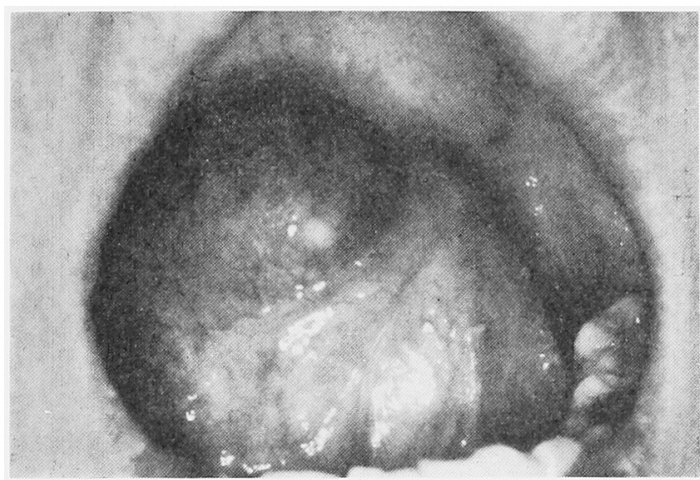

写真 2 舌下面所見

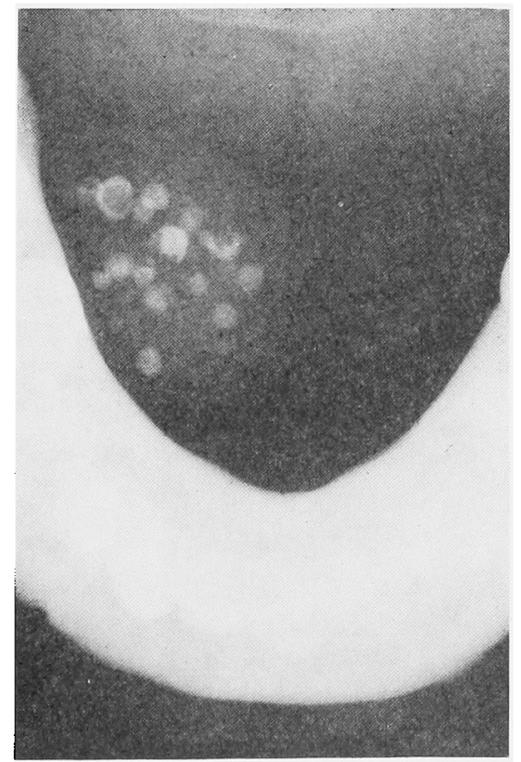

写直 3 舌の咬合法X線写真
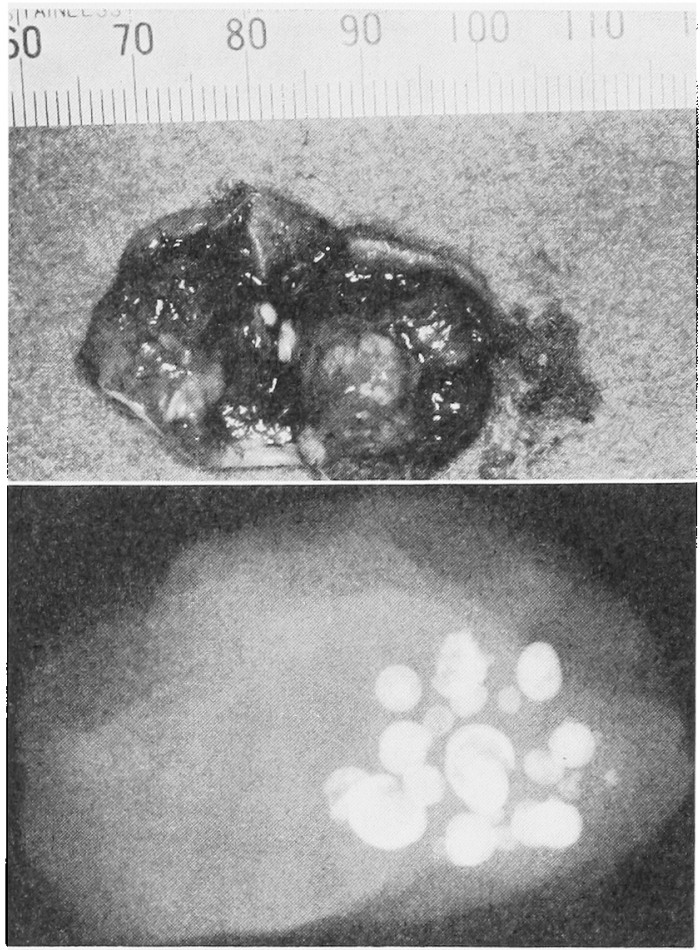

写真 4 摘出物所見

4-a 摘出物の割面所見 (上)

$4-\mathrm{b}$ 摘出物のX線写真 (下)

処置および経過：上記診断のもとに，入院の上, GOF 全身麻酔下で尰瑒を周囲組織を含めて一塊として摘出し た．手術直後，舌に軽度の運動障害がみられたが，知覚 麻疩ならびに味覚障害は認められなかった。術後の経過 は良好で，再発もなく，運動機能すすぐに回復した。

摘出物所見：摘出物の表面は滑沢で暗赤紫色を呈し, 硬さは弾性軟, 大きさは $3 \times 2 \times 3 \mathrm{~cm}$ であった（写真 4 a). なお，摘出物中に存在する結石を確認する目的 でX線撮影を行ったところ，10個以上の栗粒大から小豆 大の比較的明瞭な輪郭を呈した結石を認め, それらは腫 瘍内に不規則飞散在していた（写真 $4 \mathrm{~b}$ )。摘出した血 管腫に含まれていた結石はほほ類円形を呈し，色は灰白 色で表面はやや粗造で凸を有していた（写真 5).

病理組織所見：H-E 染色で上皮下結合組織执よび舌 の横紋筋層内に，内面を内皮細胞で一層拈おわれた血管 の增殖が観察された。また，一部に石灰化物も確認され た. 病理組織診断は，石灰化物を伴った海綿状血管腫で あった（写真 6 ).

\section{走査型電子顕微鏡所見および分析結果}

走查型電子顕微鏡所見：観察には，大，中，小の静脈 
石を用いた，試料は各々，通法に従って凍結割断し，電 界放射型走査電子顕微鏡 (HITACHI S-700) で観察し $\star^{11)}$

弱払大で小さめの試料を検索すると，試料全体が均一 な層状構造を示していた，強拻大でみると，その表面は 線維状構造物より成って拈り，それらの走行はほぼ一定 方向を示し, 太さもはぼ均一であった(写真 $7 \mathbf{a}, 7 \mathbf{b}$ ).

中程度の大きさの試料では, 弱拡大で小さめの試料と 同様に層状構造がられた．しかし，強拡大では，その 線維状搆造物の走行は若于乱れていた。ささらに線維状構 造物の間には無構造な沈着物の形成がみられた（写真 8 a, 8 b).

比較的大さめの試料に和いては，弱拡大で周辺部には 層状構造がみられたが，中心部には空洞と思わせる部分 が認められた．強拻大では線維状構造物はほとんどみら

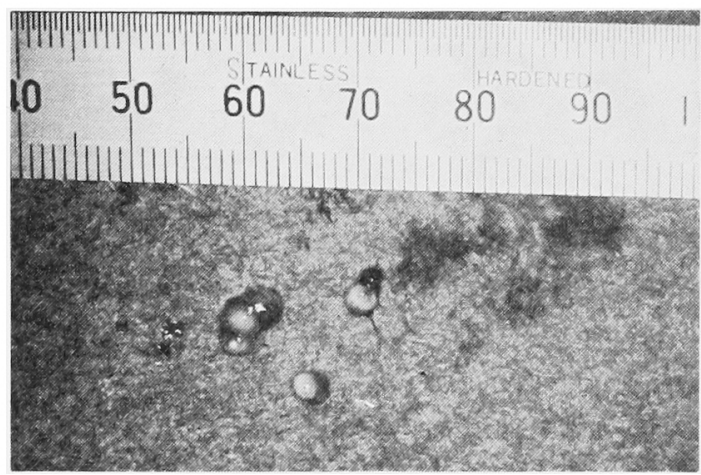

写真 5 結石の所見
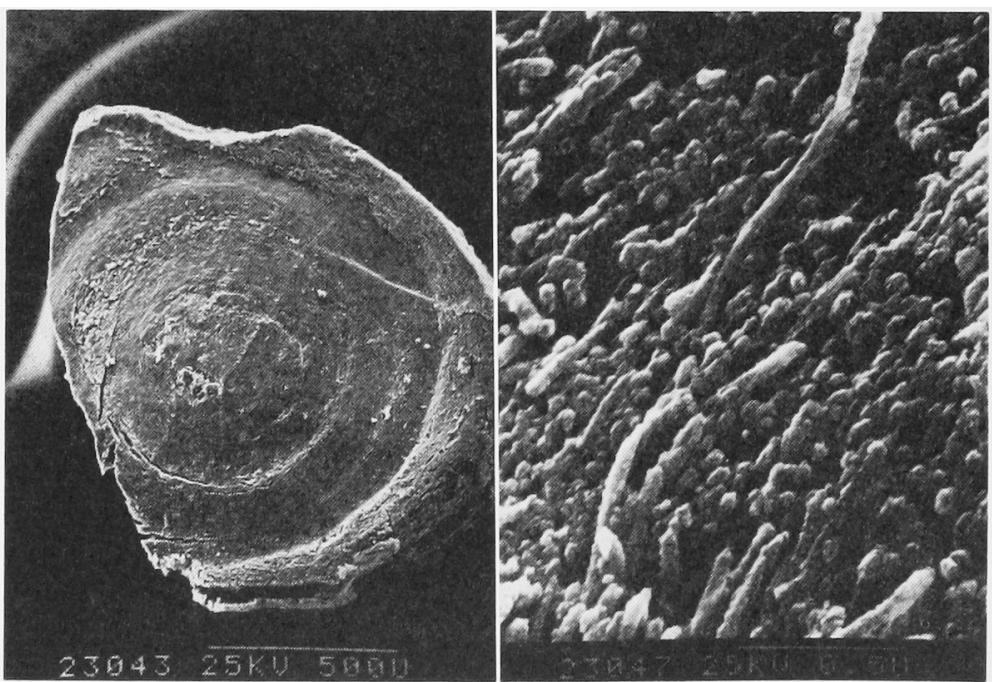

写真 7 小さめの試料の電子顕微鏡所見

7-a 㐷扰大（左）

7-b 強拡大（右）
れなくなり，無構造な沈着物が著明に現われ，その沈着 物湶維状構造物が包及込まれるよらな所見が認められ た（写真 $9 \mathbf{a}, 9 \mathbf{b})$.

マイクロラジオグラフィーによる所見：マイクロラシ オグラフィーは, 通法に従って小さめの試料について厚

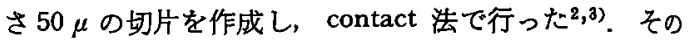
結果, 静脈石全体が㬝状に石灰化していることが確認さ れた (写真10).

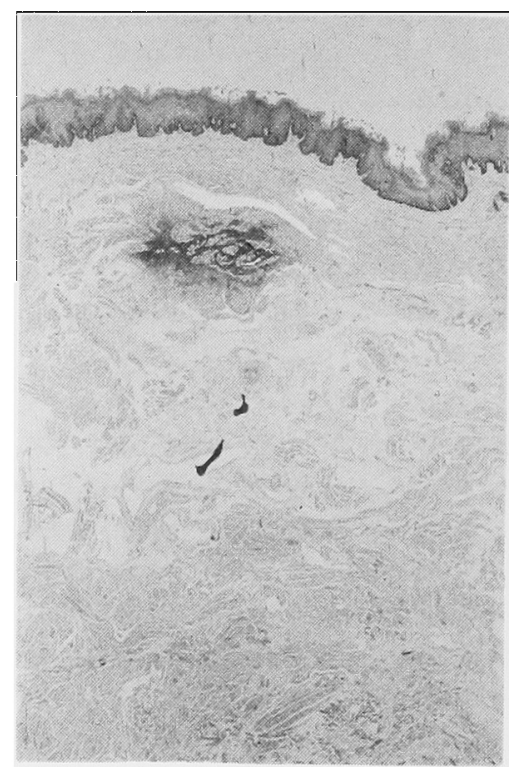

写真 6 病理組織所見 


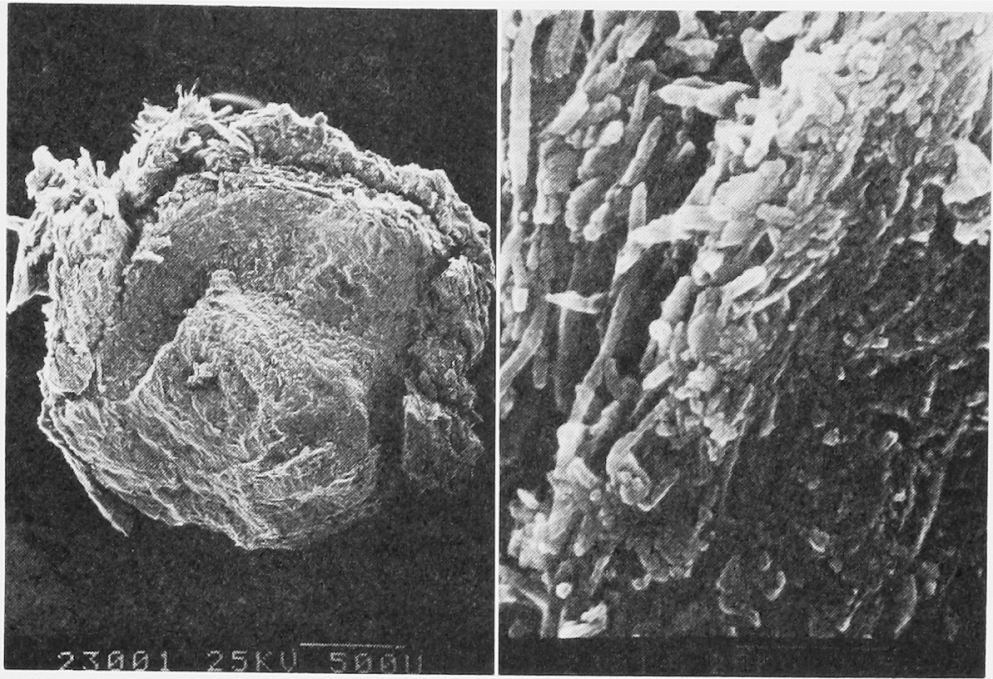

写真 8 中程度の試料の電子顕微鏡所芫

8-a 諮拡大（左）

8-b 強抎大（右）

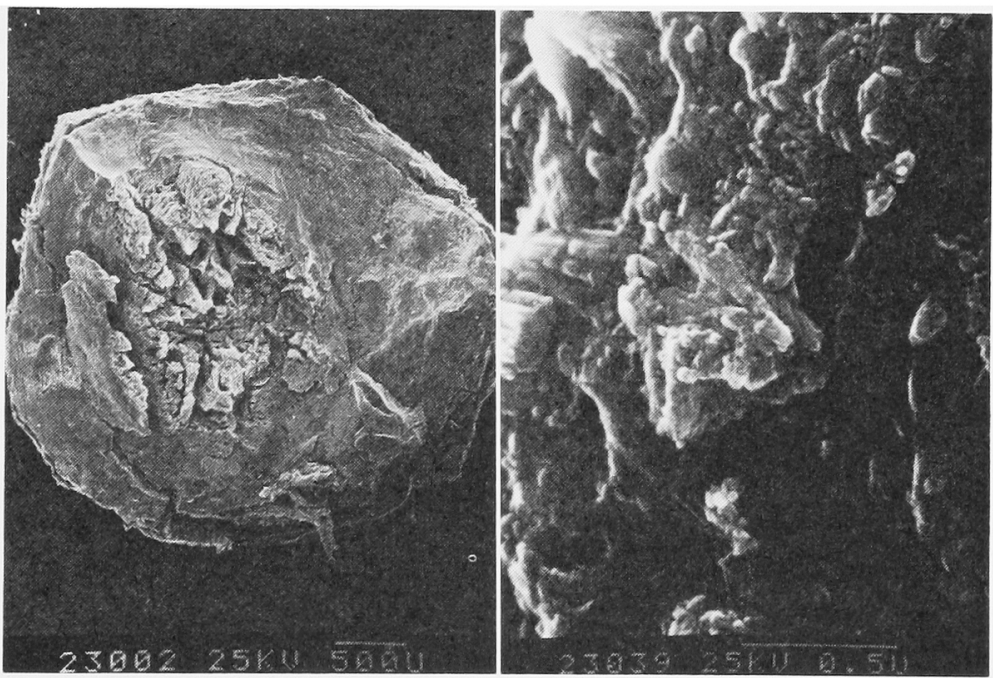

写真 9 大きめの試料の電子顕微鏡所見

9-a 弱桩大（左）

9-b 強玹大（右）

元素分析：試料をポリエステル樹脂に包埋した後，厚 さ50 $\mu$ の切片を作成し，分散X線分析装置 (KEVEX7000）にて元素分析を行った1).

その結果, 静脈石の主な元素ははとんどが Ca と $\mathrm{P}$ であり，一部の試料では微量ではあるが $\mathrm{Na} と \mathrm{Mg}$ の 存在が諰められた（図1).ささらに，元素分析に用いた 陚料から Ca と P の比を求めたところ, 重量比は1.98 〜2.16, モル比は1.53〜1.67であった（表 1).
成分分析：分析には 4 つの静脈石を用い，直接灭化法 で行った4).

水分扰よび無機成分の含有量は各々7.7 8.0\%，82 $89 \%$ でったが，有機成分については 3〜11\%と試料に より差がみられた。 また， $\mathrm{Ca}$ と $\mathrm{P}$ の重量比を測定し たところ，その比は1.90〜2.30であった（表 2). 


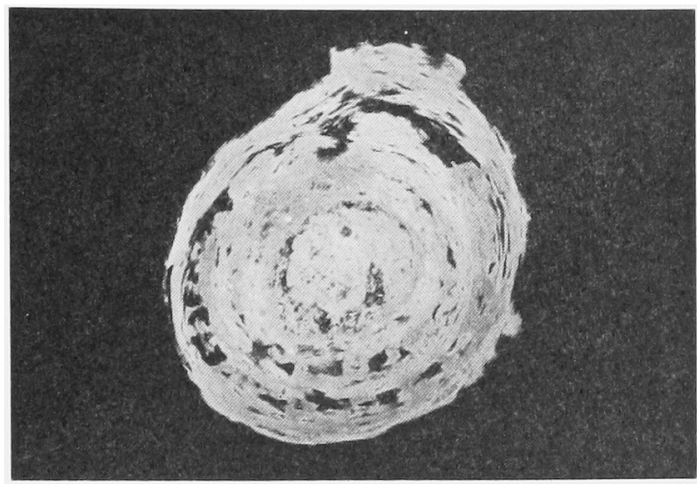

写真 10 マイクロラジオクラフィ一所見

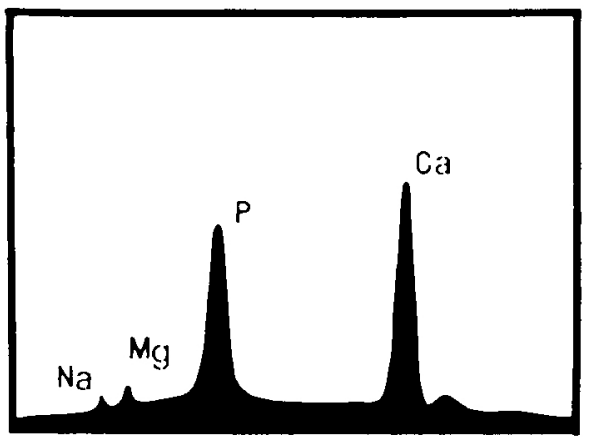

図 1 元素分析

考

察

口腔領域において，多数の静脈石を伴った血管腫の報 告は過去にいくつかあるものの比較的少ない，今回われ われは，10個以上の静脈石を伴った海綿状血管腫に遭遇 した，そこでここれらの静脈石について，走查型電子顕 微鏡による観察批よびマイクロラジオグラフィー, 分散 X線分析装置による元素分析, さらに化学的分析を試及 た。な祘脈石の形態は粟粒大から小豆大の大きさで， ほとんどが類円形をなし，表面は粗造であった、これら の所見はこれまでの報告と一致していた2,3,5 ?)

走查型電子顕微鏡比上る観察では，弱拆大で静脈石が 中心部から同心円状飞層状構造を呈しているのが認めら れた。ささらにこの静脈石が層状に石灰化していること が，マイクロラジオグラフィーの所見から確認された。

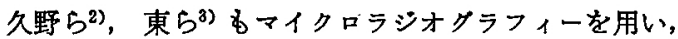
静脈石が曆状に石灰化していることを報告している。 こ の試料を強払大で観察すると，その表面は線維状椿造物 より成っていた，興味ある知見は，試料が大きくなると 線維状構造物の間に無構造な沈着物の形成がみられたこ とである。この沈着物は線維状構造物を包み込むように
表 1 元䒚分析から求めた $\mathrm{Ca} / \mathrm{P}$ 比

\begin{tabular}{r|c|c}
\hline 試 & 重量比 & モル 比 \\
\hline $1-1$ & 2.11 & 1.63 \\
2 & 1.98 & 1.53 \\
3 & 2.07 & 1.60 \\
\hline $2-1$ & 2.09 & 1.62 \\
2 & 2.15 & 1.66 \\
3 & 2.16 & 1.67 \\
\hline $3-1$ & 2.08 & 1.61 \\
2 & 2.01 & 1.55 \\
\hline $4-1$ & 2.10 & 1.62 \\
2 & 2.11 & 1.63 \\
\hline 平 & 2.09 & 1.61 \\
\hline
\end{tabular}

表 2 静脈石の成分分析

\begin{tabular}{c|c|c|c|c}
\hline 試料 & 水分 $\%$ & 有機成分 $\%$ & 無機成分\% & $\begin{array}{c}\mathrm{Ca} / \mathbf{P} \\
\text { 重量比 }\end{array}$ \\
\hline 1 & 7.66 & 10.58 & 81.76 & 2.14 \\
2 & 7.92 & 10.42 & 81.66 & 2.30 \\
3 & 7.83 & 4.35 & 87.82 & 2.17 \\
4 & 8.00 & 3.00 & 89.00 & 1.90 \\
\hline 平㘬 & 7.85 & 7.09 & 85.06 & 2.13 \\
\hline
\end{tabular}

存在し，大きな静脈石ほどその形成も多くなる傾向がみ られた，この沈着物が増加するにつれて線維の走行仕乱 れ，また，同心円状の層状構造も不規則になっていっ た、なぜこのよらな変化が起きたのかは明らかでない が，静脈石の成分分析を行ったところ，標本により有機 成分にかなりの違いがみられたことから，無構造な沈着 物が組織中の有機成分の変化を反映している可能珄が考 克らる。

元素分析では，一部に $\mathrm{Na} ， \mathrm{Mg}$ が含まれていたすの の, 静脈石の主要構成元素は $\mathrm{Ca}$ と $\mathrm{P}$ であった。これ 飞対し，久野ら²報告では $\mathrm{Ca}$ と $\mathrm{P}$ のほが $\mathrm{Mg}$, $\mathrm{S}, \mathrm{K}, \mathrm{Cl}, \mathrm{Fe}, \mathrm{Zn}$ が，また東ら $\mathrm{Cl}, \mathrm{K}, \mathrm{Cu}, \mathrm{Fe} ， \mathrm{Si}$ が検出されたことを報告している。 しかしいずれる主成分が $\mathrm{Ca}$ と $\mathrm{P}$ であることはわれわ れの報告と一致しており，扇内らり む同様の報告をして いる．扰そらくこの構成元素の違いは，組織中汇含采れ る有機成分古るい性血清成分によるものと考兄られる。

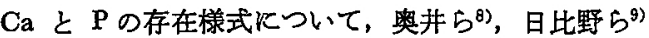
は静脈石を粉末にしてX線解析を行い，合成ハイドロキ シアバタイトと類似のものであると報告している，われ われの研究に颃いても，元素分析あるいは成分分析より 
$\mathrm{Ca}$ と $\mathrm{P}$ の重量比, モル比を算定すると, その值は八 イドロキシアパタイトの值と近似して拈り, おそらく $\mathrm{Ca}$ と $\mathrm{P}$ はハトトロキシアパタイトとして存在してい るものと考えられる.

成分分析の結果, 扇内ら ${ }^{7)}$ は水分 $4.8 \sim 7.2 \%$, 有機成 分29 35\%, 無機成分59〜66\%, また, 日比野ら ${ }^{9)}$ は水 分 $10.5 \%$ ，有機成分 $40.9 \%$ ，無機成分 $48.6 \%$ と報告して いる.これらの值は有機成分や無機成分の値で，われわ れの結果と大きく異なり, われわれの症例の方が石灰化 が進んでいるように思われた。 その理由については不明 であるが，彼らの症例はいずれも子供であること，しか も気が付いてから摘出までの期間がかなり短いといら点 で，われわれの症例と異なっていた，骨，エナメル質， 象牙質の石灰化は, 時間とともに一定程度まで進行する といわれていることから ${ }^{11)}$, 摘出するまでの期間あるい は患者の年跉が静脈石の石灰化の程度に関連しているこ とが推測される。

今回われわれは, 静脈石のアミノ酸分析は行っていな (が, 扇内ら ${ }^{7)}$, 日比野 ${ }^{9)}$, 金沢ら ${ }^{10)}$ のアミノ酸分析 では, グリシンがもっとも多く、コラーゲンに類似した 物質も含まれていたと報告している。このことより，走 査型電子顕微鏡でみられた線維状構造物がコラーゲン類 似物と考えられるかもしれない、また，石灰化がコラー ゲン線維に沿って進んで行くことは骨や象牙質でよく知 られていることである12). したがって，この線維状構造 物に沿って層状に石灰化が進んでいったものと思われ る.

静脈石の形成機序については, 現在まで明確にされて いない.この点についてわれわれは次のように考えてい る. 血清中のカルシウムイオンとリン酸イオンの積は, ハイドロキシアパタイトに対して飽和状態であることが 知られている13) したがって, 局所のカルシウムイオン やリン酸イオンの濃度が上昇したり，あるいは石灰化の 核が形成されれば，石灰化が進行するものと考えられ る. 現在また, 血清中にはプロトロンビンのように, Gla 残基を持つカルシウムイオンと結合能の高いタンパ ク質が存在することが報告されている14).これらのこと より，何らかの局所的原因により局所のカルシウムとリ ン酸イオンの積の上昇, あるいはカルシウムイオンと結 合能の高いタンバク質がカルシウムイオンと結合し, こ れにリン酸イオンとカルシウムイオンとが順次添加し て，まず核が形成されれば，石灰化が漸次進行して静脈 石が形成されるのではないかと考えられる.

\section{結語}

われわれは静脈石を伴った舌血管腫を経験し, その静
脈石についてX線元素分析, 成分分析および電子顕微鏡 による観察を行った。 その結果，X線元素分析について は今までの報告とほぼ一致していたが，成分分析では多 少異なった所見がえられた。 また，電子顕铛鏡による観 察では静脈石の大きさにより，その内部構造に違いのあ ることが確認できた.

本論文の要旨は, 第 134 回日本口腔外科学会関東地方 会（昭和61年 3 月 1 日, 東京) で発表した。

\section{引用文 献}

1）倉地洋一，松本英彦，他：走査電子顕微鏡によ る唾石の観察。日口外誌 26：945-951 1980.

2) 久野吉雄, 東 俊雄, 他: 静脈石を有した口腔 底血管腫の 1 例。 日口外誌 15：44-47 1969.

3) 東 俊雄, 比嘉実盛, 他: 静脈石を有した舌下 血管腫の 1 例とその静脈石の Electoron Microprobe Analyzer による分析結果について。 日 口外誌 16: 53-59 1970.

4）小原哲二郎, 他監修：食品分析ハンドブック. 第 5 版, 建帛社, 東京, 1982, 259-260頁.

5）寺井宏, 堀部紘: 静脈石を伴った煩部海線 状血管腫の 1 例。口科誌 20：105-108 1971.

6) 增田正樹, 成宮正光, 他: 多数の結石を有する オトガイ下口底部血管腫の 1 例. 日口外誌 17 : 428-431 1971.

7）扇内秀樹, 山下泰裕, 他：静脈石を伴った頓部 血管腫の 1 例. 日口外誌 31：108-113 1985.

8）奥井 寛, 下里常弘, 他: 頓部血管腫中にみら れた静脈石の物理化学的性状に関する研究. 口 科誌 26: 61-71 1977 .

9）日比野修, 大西正俊, 他: 初回手術後に䋫脈 石の形成をみた頓部血管腫の 1 例. 一その臨床 経過ならびに静脈石の物理化学的性状につい て一。 日外誌 26: 1300-1307 1980 .

10）金沢拓実, 久保木芳徳, 他: 異所石灰化組織の 有機基質について。骨代謝 12：434-440 1979.

11) 須田立雄, 他監修: 口腔生化学. 第 1 版, 医歯 薬出版, 東京, 1987, 94-100頁.

12）小澤英雄, 他監修: 骨の化学. 第 1 肘, 医料薬 出版, 東京, 1985, 136-139頁.

13）小澤英雄, 他監修: 骨の化学. 第 1 版, 医歯薬 出版, 東京, 1985, 133-136頁.

14）須田立雄, 他監修: 口腔生化学. 第 1 版, 医菌 薬出版, 東京, 1987, 59-61頁. 